https://helda.helsinki.fi

Promoting knowledge practices in upper secondary schools :

Case studies from Finland and Bulgaria

\title{
llomäki, Liisa
}

2020-01-02

llomäki , L , Stefanova , S \& Vasileva , T 2020 , ' Promoting knowledge practices in upper secondary schools : Case studies from Finland and Bulgaria ', Research Papers in

Education, vol. 35 , no. 1 , pp. 43-63 . https://doi.org/10.1080/02671522.2019.1677753

http://hdl.handle.net/10138/329312

https://doi.org/10.1080/02671522.2019.1677753

acceptedVersion

Downloaded from Helda, University of Helsinki institutional repository.

This is an electronic reprint of the original article.

This reprint may differ from the original in pagination and typographic detail.

Please cite the original version. 


\title{
Promoting Knowledge Practices in Upper Secondary Schools: Case Studies from Finland and Bulgaria
}

\author{
Liisa Ilomäki ${ }^{*}$, Tania Vasileva ${ }^{\mathrm{b}}$ and Stela Stefanova ${ }^{\mathrm{c}}$ \\ * Faculty of Educational Sciences, University of Helsinki, Helsinki, Finland \\ ${ }^{b}$ Faculty of Electronic Engineering and Technology, Department of Electronics, Technical \\ University of Sofia, Sofia, Bulgaria \\ ${ }^{c}$ Technology school Electronic systems, associated with Technical University of Sofia, \\ Bulgaria
}

*Corresponding author Liisa Ilomäki, P.O. Box 9, 00014 University of Helsinki, Finland liisa.ilomaki@helsinki.fi

Liisa Ilomäki, EdD., Docent (Adjunct professor) in education and technology, works at the University of Helsinki, Finland. Her research interests include the use of digital technologies in learning and teaching and the development of students' knowledge work competence. Ilomäki has been involved in several European and national research projects in technology-enhanced learning.

Tania Vasileva, $\mathrm{PhD}$, is a professor of electronic engineering at the Technical University of Sofia, Bulgaria. She has taught several courses on semiconductor devices, VLSI and ASIC design. Currently she is the Scientific Manager of the Electronics Systems Technology School associated with the Technical University. Her research interests include collaborative learning and using cloud computing in education.

Stela Stefanova, Ph.D., is currently working as an associate professor and principal in the Electronic Systems Technology School associated with the Technical University of Sofia. Her teaching activities are in the fields of CAD Systems in Electronics and Computer networking with intensive use of information and communication technologies. 


\section{Promoting Knowledge Practices in Upper Secondary Schools: Case Studies from Finland and Bulgaria}

This exploratory case study was conducted in two upper secondary schools in Finland and Bulgaria. The aim of the study was to investigate how to apply trialogical design principles could be used to improve students' knowledge work competencies, and teachers' re-structured obligatory courses following pedagogical design principles for knowledge creation practices. The courses were organised in the form of students' collaborative inquiry and project work. The research questions focused on the implementation of the design principles, students' self-assessed learning of knowledge work competencies and the experiences of students and teachers. The main data consisted of students' self-evaluation answers to a pre-questionnaire $(\mathrm{N}=76)$ and a postquestionnaire $\mathrm{N}=52)$, and teachers' $(\mathrm{N}=4)$ plans and interviews. The results showed that students' experiences were positive, but they also found shortcomings in their knowledge work competencies. The teachers were also satisfied with the experiences, but they found problems in teachers' collaborative planning at the end of the process (in Finland) and in organising student teamwork and in reporting the contributions (in Bulgaria). The set of design principles was useful as a collaborative guidance tool for the teachers' planning, and in these two cases, the form of an inquiry learning and project work. However, the teachers need practical guidelines to implement the trialogical design principles.

Keywords: knowledge work competence; upper secondary school; pedagogy: change 


\section{Introduction}

There has been criticism that upper secondary school students do not have the necessary competencies to undertake further education and to cope in the work, such as information processing, teamwork, communication, presentation or digital competencies (Hautamäki, et al. 2012; Kiili 2012; Lundahl et al. 2010; OECD 2010; 2015). The terms used to describe these general competencies vary: they are called, e.g., 21st century skills (see Voogt \& Roblin 2012; Hilton 2012), future competencies or skills, generic competencies, key competencies (Kearney 2012; Westera 2001), or knowledge work competencies (Muukkonen et al. 2017). These terms show that the content of the phenomenon is still evolving and that there is not yet a generally accepted term nor consensus about the content (Hilton 2015). Nonetheless, the terms are close to each other in relation to what individual competencies they include. In this study, we use the term 'knowledge work competence', and we refer to knowledge, skills and disposition to act, study and work intentionally and effectively both individually and with others in a range of contexts. Knowledge work competencies enable complex problems to be solved and involvement in creating knowledge and novel solutions by using the community's collective technology-mediated efforts (Ilomäki et al. work in progress).

Studies concerning learning various individual competencies indicate that complex competencies only evolve through extensive, repeated, versatile, and long-term practice, which should be enabled in varying instructional contexts throughout the study years (Kay 2009; Lakkala, Ilomäki, and Kantosalo 2011). For example, in their study about learning information literacy skills by a process of Guided Inquiry, Heinström and Sormunen (2018) stated that it is important to reserve time to create students' interest and ownership, and to develop a genuine open research question for exploring a topic. In addition, it is necessary to structure and focus the process rather than focusing on outcomes. In our study earlier 
(Ilomäki, Paavola, Lakkala and Kantosalo 2014), based on a review of digital competence, we suggested that digital competence develops in problem-oriented, technology-rich and long-term settings in which technology is used in a meaningful context, and a range of technological tools are used in integrated ways.

Several initiatives and ideas have been set up to promote the acquisition of relevant general competencies at secondary level, including the following:

(1) Suggestions for increasing enterprise contacts through students working in enterprises (European Commission 2012b; Davis and Gueldenzoph Snyder 2009) or initiatives to increase entrepreneurship education for improving school-work connections between teachers and the external world as well more in-depth cooperation with companies (Ruskovaara and Pihkala 2015). In several countries, students have short periods when they must work in a workplace but these periods are usually too short to learn competencies, and there are no connections to ordinary school pedagogy. Therefore, students' experiences of enterprises might be dismissed at school, although they could offer an option for learning work-related competencies (Herring 2011).

(2) Connections with higher education to improve upper secondary students' competencies provide academic opportunities for cross-fertilisation. For example, in a study by Hammond, Karlin, and Thimonier (2010), upper secondary students participated in a biology project in university laboratories. Good collaboration and learning outcomes were experienced, but the implementation was demanding for both the school and the university.

(3) Project-based and inquiry learning as pedagogical approaches emphasise students' responsibilities and engagement (Bell 2012; Heinström and Sormunen, 2018; Lam, Cheng, and Choy 2010; Pitura and Berlinska-Kopec 2018; Shuptrine 2013; Wang et al. 2011). These models are often connected to increasing authenticity and digital tools in inquiry or project work processes, as e.g., Pitura and Berlinska-Kopec (2009) described an English learning 
project work about cultural heritage using digital tools. Other examples of these are learning science through one's own inquiries, as described by Huffling et al. (2014), or using microblogs (Rasmussen and Hagen 2015).

(4) Hilton (2012) connected learning of general competencies to characteristics of deep learning, such as multiple and varied representations of concepts and tasks; encouraging elaboration, questioning, and explanation; engaging learners in challenging tasks, while also supporting them with guidance, feedback, and encouragement to reflect; teaching with examples and cases; and priming student motivation by connecting topics to students' personal lives and interests, engaging them in collaborative problem solving. She considered whether the same methods also support inter- and intrapersonal skills, such as teamwork or self-regulation.

However, the various pedagogical practices do not support the development of the competencies per se, and detailed pedagogical implementation solutions, adapted in the context and students, are needed for successful outcomes (Shulptrine 2013; Wang et al. 2011). In addition to the challenges of pedagogical practices, the to teach general competencies is an organisational challenge for teachers and schools since traditionally the curriculum is often theory-based and divided into subjects which are taught by teachers specialised in a specific subject. Integrated entities across several domains or projects have been rare and occasional. Pedagogical implementation solutions are still missing and there is a gap between the requirements general competencies to be taught in upper school and the research evidence about how to effect changes in pedagogical practices.

In higher education, the knowledge creation approach and trialogical design principles (DPs) (Paavola and Hakkarainen 2009; Paavola et al. 2011) were created to provide pedagogical approaches which promote students' knowledge work competencies. The trialogical design principles are the following: 
DP1) Organising students' activities around shared objects. Tasks and activities include collaborative work on improving tangible shared objects, such as plans, reports, and media products.

DP2) Supporting integration of personal and collective agency and work through developing shared objects. Tasks and work criteria are designed so that learners must take responsibility for their own efforts as well as advancing shared goals and tasks. In an ideal situation, the requirements combine individual goals with collective goals.

DP3) Emphasising development and creativity in working on shared objects through transformations and reflection. The phenomena are examined by using different forms of knowledge and artefact types, such as theoretical constructs, practical work, problem solving, discussions, and various media types, as well as by engaging in continuous reflection of practices and outcomes.

DP4) Fostering long-term processes of knowledge advancement with shared objects instead of requiring fast outcomes without feedback, versioning and improvements. Developing shared objects takes place in sustained, prolonged, and iterative working processes. The outcomes and practices have further use for the learners or other stakeholders.

DP5) Promoting cross-fertilisation of various knowledge practices and artefacts across communities and institutions. Fruitful learning practices include influences with external communities and organisations and collaboration between participants from separate groups and institutions.

DP6) Providing flexible tools for developing artefacts and practices. Modern digital tools are used purposefully and effectively to support collaborative work on shared objects as well as to enable flexible mobility and co-construction in various representational forms.

The results of using trialogical design principles for pedagogical improvement in higher education have been promising although it is demanding for the lecturers to apply 
them in practice, for organisational reasons, time limits or for the teacher's own suspiciousness (Lakkala et al. 2012; Lakkala et al. 2015; Muukkonen et al. 2017; Sansone, Cesareni, and Bortolotti 2018; Vasileva and Tchoumatchenko 2014; Vasileva, Tchoumatchenko, and Manoeva 2015). In this study, the major aim was to create such pedagogical practices which support upper secondary students' knowledge work competencies. For this aim, we focused on investigating whether trialogical design principles can be applied as implementation solutions in upper secondary education and whether the design principles helped teachers to improve and transform their pedagogical practices during participation in a development project, as the results and experiences in higher education have indicated. A practical aim was also to help schools and teachers with guidelines for transforming practices to fill the gap currently experiences in knowledge work competencies. To answer these aims, we focused on students' and teachers' opinions about the new pedagogical practices and students' evolving competencies during the new or improved courses.

\section{Research Questions}

The research questions were the following:

(1) How were the design principles implemented in courses?

(2) How did students evaluate the learning of knowledge work competencies and course experiences?

(3) How did the teachers evaluate the collaborative planning and realisation of the courses?

\section{Methodology}

The explorative multiple case study consisted of two cases from upper secondary schools in 
Finland and in Bulgaria. The study has characteristics of design-based research: the participating teachers were guided in applying a new pedagogical approach and the first plans were created on a theory-driven template. The results of the implementation were investigated, the courses were improved, and the design and the implementation provided a test bed for a theoretical innovation and was theoretically justified (Cobb et al. 2003).

For the data collection, we used a mixed methods approach to shed light on the authentic and complex phenomena investigated (Newman et al. 2003).

\section{The Context}

The present study was conducted in the context of an international KNORK project (Promoting Knowledge Work Practices in Education, http://knork.info/website/) which was a pedagogical development and research project during in 2014-2016. The courses selected for investigation were among the first courses of the project and were particularly interesting because the participating teachers re-designed the courses with the intention of promoting students' knowledge work competence.

In both countries, students' general competencies have become a topic for educational discussion. In Finland, the new curriculum for upper secondary schools emphasises experiences of learning across subjects, multiple ways of creating knowledge, learning to evaluate knowledge, support for multiliteracy skills as well as learning to use digital technology in a meaningful, responsible and safe way, both individually and collaboratively (Opetushallitus 2015; Krokfors 2017). In Bulgaria, representatives from labour market have collaborated with educators to identify the competencies upper secondary professional school students should have acquired as the outcomes of their education. They suggested that skills such as group work, collaborative learning, networking, learning to learn skills, creative and critical thinking, communication, social skills, presentation competence, flexibility, and leadership, are all critical for better adaptation to the continually-changing world. 
Recommendations for the updated curriculum were developed and the integrated curriculum provides students with opportunities to work on tasks and assignments that have a career focus (see https://sites.google.com/site/bulgariancurriculum/).

\section{Educational Interventions}

Three teachers from the Finnish school and one teacher from the Bulgarian school participated in a European-level half-day workshop in January 2014 in which they were guided in using trialogial design principles (Paavola et al. 2011; Paavola and Hakkarainen 2009) to restructure or create a course plan. Participants used a design template based on the design principles and the trainers commented on their plans. After the workshop, the researchers consulted the Finnish teachers a several times before and during the planned course. A university manager from the university supported the Bulgarian teachers during course transformation.

\section{The Investigated Cases}

\section{The Finnish Case}

The Finnish school is located in a suburb of Helsinki. It has about 600 students and 54 teachers. The school follows the basic national upper secondary curriculum, and it has implemented a special curriculum emphasising media arts. The school has been active in various ICT and development projects. A special challenge for upper secondary level Finnish teachers of has been the digitalisation of the final examinations during 2016-2018. Teachers needed to improve their digital competence, but especially the pedagogical skills of using digital technology in their teaching, and this was a background for this case. 
Three teachers created an integrated course assignment based on phenomenon-based learning (Francis, Østergaard, \& Morse 2013). The case combined obligatory courses in biology, chemistry and physics. The reason for selecting these three courses was that the first upper secondary school courses in these subjects are full of fragmented information and there is no time to expand them into an integrated whole. Energy is discussed in all these courses, but from different viewpoints. With one joint theme, the students would gain a better overall understanding about energy, and they would also some generic work competencies.

All 67 students from the three courses participated in the process. Teachers conducted the courses as previously, but for the students in all courses, there was a common assignment, 'Energy in the ecosystem', as an overall topic of collaborative inquiry. The project lasted for seven weeks, as long as the courses, and the project took one-third of the time scheduled for the courses. Students also worked at home on the project. The project started with a joint brainstorming session about the phenomena. This took place at a schoolyard barbecue while creating new ideas. Students formed groups based on their interests of the sub-topics. The task the groups had was to create answers and material about the phenomenon they had chosen to examine. The groups were supposed to combine all the materials into a larger entity to be used as study material in future courses at the school. An expert from a solar system company participated in the process by giving an expert lecture to the students in the middle of the project. Students used Google documents for sharing and co-authoring material and the final product was constructed as a Prezi presentation.

\section{The Bulgarian Case}

The Bulgarian school is located in Sofia. It has about 550 students and 42 teachers. The school follows the basic upper secondary curriculum, and it has implemented a special curriculum that emphasises information and communication technologies, system programming and computer networking. Because of the professional ICT orientation of the 
school, all teachers and students have excellent digital competence, and they actively participate in many national and international activities in the field. The school is a part of the Technical University of Sofia, and some of the school teachers have doctoral degrees. Transferring teachers, educational approaches and ideas between the school and university is common. Collaborative work contracts between the school and the university enable school teachers to participate in research and in international projects. University lecturers and experts from industry are involved in guiding students in their school diplomas. The Education Law promotes the introduction of innovative schools at which non-traditional educational approaches can be used in active co-operation with universities and representatives from industry and research institutes. Examples of this are specific technical courses with more scientific and academic content taught by university lecturers (Vasileva and Stefanova 2014) and a robotic systems course connected to industry (Nikolov 2015).

Two teachers organised two Computer Aided Design (CAD) courses in electronics for eleventh-grade secondary students. One teacher was responsible for the theory, and the other teacher was responsible for practice. The courses for the two classes took place in the same semester but at a different time.

In all, 52 students participated in the two courses. The courses took 18 weeks, five hours per week, of which two hours were devoted to theory and three hours to practical training. The practical training parts of the courses were restructured according to design principles. Groups of two or three students had a large project task which was based on a sustained work process, a shared work plan and final presentations in groups. For the project, students were required to gather information, discuss the problem in a collaborative webbased environment, analyse and simulate the functioning of a digital or analogue circuit using CAD software (SPICE, Orcad and other CAD tools) specialised for circuit design. During the work process, students iteratively performed several simulations to analyse designed circuits 
and refined circuit parameters and characteristics. The three-month-long project was divided into several phases for which partially-shared reports had to be prepared. The students documented their work at every step of the development process. In addition to the large project assignment, students had weekly assignments, which were structured in 12 tasks thematically related to the more important theory topics, and these tasks were the milestones in the long-term projects. This homework was presented, discussed and analysed in class.

Students used free cloud service applications: Google Groups areas for sending emails and messages; each team had a workspace in Google Drive; and the project report was created in Google Drive as a shared document between the team members and the teacher. Each team folder was shared with other teams for commenting on and observing results, but without editing rights. Students used also forums, blogs and social media to discuss problems. They were encouraged to use other collaborative professional tools: Skype for face-to-face and virtual meetings, Google+ for discussions and Google Apps for project management.

\section{Participants}

Sixty-seven Finnish students aged 17-18 participated in the courses. The students were ordinary upper secondary school students. The Finnish teachers were aged 32, 41 and 50, two men and one woman. They were all familiar with digital technology in teaching. The teachers' subjects were physics, chemistry and biology.

The Bulgarian students were 16-17 years old. The students were from two classes from the computer networking special track. The Bulgarian teachers (both female) were aged 26 and 56 and familiar with digital technology in teaching. The older of the two was also the school principal. She was an experienced teacher and her subject domain was computer-aided design, computer networking and digital signal processing. She had also previously 
participated in national and international EU projects in the field of vocational education. The younger teacher was less experienced in teaching but had good competence in using digital technology.

All participants were asked for their permission and they participated in the study voluntarily.

\section{Measures}

The data were collected during the first half of 2014, from January until June. The data from the cases consisted of the following:

Teachers' preliminary plans for revising or creating a course based on trialogical design principles. Teachers created them at the first European-level workshop held on 10 January 2014. The data from the plans were compared with teachers' self-reflections to provide information about how the actual case was to be conducted. The data were used to answer research question 1 .

Teachers' self-reflections after the course. The Finnish teachers were interviewed ingroup, and the Bulgarian teacher provided written responses to the same interview questions. The interview was transcribed, and the descriptions were used to gain a better understanding about the implementation of design principles and teachers' experiences. The data were used to answer research questions 1 and 3.

Additional data reflecting the courses were collected for understanding the context and getting an overview of the course. The data consisted of observations in the Finnish school in Feb-May 2014 and an article by Stefanova and Vasileva (2014) reflecting the Bulgarian course. The data were used to shed light on the interpretations of other materials used to answer research question 1. 
The Students' pre and post-questionnaires included seven Likert-type statements which focused on self-evaluated knowledge and work competencies. These were: Organising studies purposefully, analysing theoretically the topics to be studied, discussing with others the topics to be studied, taking advantage of common discussions for deepening understanding, working in a goal-oriented way in a group, developing productions collaboratively with others, and using technology in multiple ways during the collaborative work. The post-questionnaire also included two open-ended questions about the experiences with the course (what was positive during the course, what was problematic or challenging). In Finland, 66 (pre-questionnaire) / 67 (post-questionnaire) students answered, in Finnish. In Bulgaria, 52 students answered in English. The data were used to answer research question 2.

\section{Data Analyses}

Teacher interviews and the students' open-ended questions were analysed through qualitative content analysis by using ATLAS.ti software.

Teachers' preliminary plans. The analysis was based on the description of a design principle. We compared each design principle with the implementation plan and the teachers' self-reflections. The authors then decided how well the theory-based design principle and the practical implementation matched. For example, in the plan, the Finnish teachers wrote about

DP 1: 'Student groups of 3-4 persons write to Google Docs information about various 'energy' topics. ...Students read and evaluated other groups' outcomes in the middle of the project. ...the groups' summaries will be collected into an entity, e.g. as a Prezi presentation'. That description showed that students had a shared object in each group, and in addition, they had a shared overall object, energy, which the groups investigated from their own points of view. 
Teachers' self-reflections after the course. The main categories were based on the interview questions. The main categories were: Successful issues in general; Problems in general. In addition, in the Finnish data, the other categories were data-driven and based on teachers' answers: Knowledge work practices; Group work; and Changes compared with the previous iteration. In addition, the teachers described some of the practical issues of the courses which had been in the plans but were now in the solutions after the processes, such as the length of the process or the digital tools used, and these clarifications were used to answer the first research question.

Students' pre- and post-questionnaires. Students' answers to the statements in the preand post-questionnaires were analysed statistically with SPSS v24; the analysis consisted of comparing the means between the pre- and post-statements of Finnish and Bulgarian students. The open-ended answers were analysed with ATLAS.ti, an application for qualitative content analysis. The items were categorised according to the main questions (Positive issues, Challenging or disturbing issues) which made the analysis much clearer. The sub-categories were data-driven. Because the Finnish and Bulgarian students worked differently, the categories were not the same. The categories, subcategories, and examples of categories are presented in the Results.

\section{Results}

The results are presented in the same order as the research questions.

\section{Implementation of the Design Principles}

The first research question considered the implementation of design principles, as summarised in Table 1, concluded from the plans and teachers' self-reflections. 
Table 1. Implemented design principles in Finnish and Bulgarian cases

Finnish case

Bulgarian case

DP1. Organising activities around shared objects

One inquiry theme Energy for three separate One major project as a kind of customer courses. Student groups brainstormed issues project but created by the teachers for each about energy and then chose an inquiry group, supported by weekly assignments, issue. Student groups worked on inquiries, also conducted in groups. The outcome of e.g., about Wind energy, Nuclear energy, the project was a report, produced Renewable energy source, Photosynthesis, collaboratively. All groups had their own and Geothermal heat. project.

Shared work plan.

DP2. Supporting integration of personal and collective agency and work through developing shared objects

Inquiry sub-theme according to one's own

choice. Constructing the teams based on similar interests. Groups were responsible for producing written material about their theme, but teachers did not follow or supervise the contribution of individual students for group work.
Constructing the teams according to similar interests. Coordinating team members were free to choose a project offering lists of projects themes. Students shared tasks between team members and there was freedom to choose which parts of the solution each member contributed.

Collective responsibility - all members in a group should have contributed to the group solution. Students reported their individual 
contribution to the overall project.

DP3. Emphasising development and creativity in working on shared objects through transformations and reflection

The inquiry project was a longitudinal process, and there were several iterations demanding reflection. Students worked with various types of materials: at the start of the brainstorming, students used their layman's knowledge; later on, they used books and the Internet as well as expert knowledge from the solar energy company.
Continuous monitoring by students and teachers, several iterations, opponent groups who comment on each other's first drafts. Weekly assignments supported the reflection of the main project.

Students used theoretical literary sources, practical examples and cases.

DP4. Fostering long-term processes of knowledge advancement with shared objects

The project was conducted over a sevenweek period, the length of a course, 1-2 hours / week.

All materials from the groups were combined into a larger entity to be used as study material in future school courses.
The project took 18 weeks, 5 hours / week.

Outcomes of the weekly assignments were used for the longitudinal project. All materials from the groups were combined into a larger entity to be used as study material in future courses of the school.

DP5. Promoting cross-fertilisation of knowledge practices and artefacts across communities and institutions

Integration of three subjects and three Not emphasised in this project. teachers as experts; an expert from a solar 
power company participated in the process

by giving an expert lecture to the students.

DP6. Providing flexible tools for developing artefacts and practices

Mobile phones used for recording the first Open cloud services such as Skype and ideas. Open cloud services such as Google Google tools (Groups, Drive, Calendar, and Docs and Padlet, and the final product was Docs) for sharing and communication. constructed with Prezi.

Specialised CAD software.

Table 1 shows that in both cases, teachers had made several changes compared to previous teaching methods in order to follow the six design principles. Teachers of the two cases implemented the design principles differently: the Finnish case followed the ideas of inquiry and the Bulgarian case was organised as a project. All the design principles were implemented to some degree (except DP5 in the Bulgarian case). DP1 the key to trialogical practices - existed in both cases. In the Finnish case, DP2 was adopted somewhat vaguely, and DP4 was combined with traditional school practices in the Bulgarian case. DP6 was implemented especially well in both cases.

\section{Students' Evaluations of Their Competencies and the Course Experiences}

For the second research question about students' evaluation of learning knowledge work competencies and their course experiences, we used a questionnaire with seven statements and two open-ended questions (Positive issues, Challenging or disruptive issues during the project). In the following, the results of the Finnish students are presented first, followed by the results of the Bulgarian students.

\section{Finnish Students}


Finnish students' answers to the statements are presented in Figure1.

I know how to use technology in multiple ways during collaborative work

I know how to develop productions collaboratively with others

I know how to work in a goal-oriented way in a group

I know how to take advantage of common discussions for deepening my understanding I know how to discuss with others about the topics to be studied

I know how to analyse theoretically the topics to be studied

I know how to organise my studies purposefully

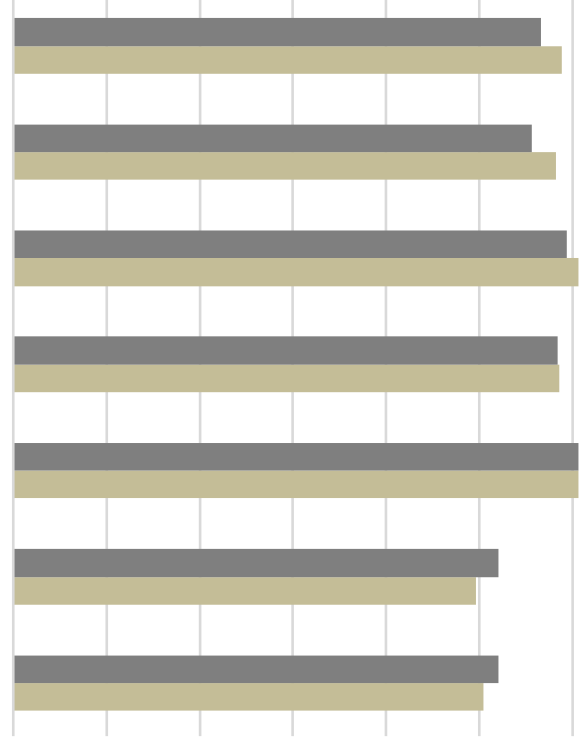

$$
\begin{aligned}
& \begin{array}{lllllllll}
1,0 & 1,5 & 2,0 & 2,5 & 3,0 & 3,5 & 4,0 & 4,5 & 5,0
\end{array} \\
& \text { - Pre }(\mathrm{N}=66) \quad \text { Post }(\mathrm{N}=67)
\end{aligned}
$$

Fig. 1. Finnish students' answers to pre-and post-statements

Among the Finnish students, the means of the pre- and post-statements were relatively high and the differences of means between the pre- and post-statements were small. The students were especially confident of their discussion skills and less confident with their skills of analysing theoretically the topics to be studied, and organising studies purposefully. There were no statistically significant differences between the pre- and post-statements. The means and standard deviations of the statements are presented in the Appendix 1.

Finnish students' answers to open-ended questions. Sixty of the students (91\% of the participants) answered the open-ended question about positive issues. Seventy positive items were mentioned, and the categorisation, number of items and examples are presented in Table 2. 
Table 2. Categories of positive issues, number of items and examples of students' answers to open-ended questions

\begin{tabular}{lll}
\hline Main category, $\mathrm{n}, \%$ & Subcategory, $\mathrm{n}$ & Example \\
\hline Learning 39 $(55 \%)$ & Course content, 9 & 'I learned where we get \\
& energy from' \\
& Difference of the course & 'We were allowed to do \\
& & something different during
\end{tabular}

Opportunity for independent

learning, 5

Interesting and fun learning, 5 'Learning better'

Other 7

Group work and

'Group work'

collaboration, 15

$(21 \%)$

Project work, 14

'Outcomes [and] several

$(20 \%)$

phases were useful'

Other: $3(4 \%)$

'No final exam'; 'I have

been able to participate in

the development of

teaching'.

In the answers to the open-ended questions, students emphasised learning: the content or learning in different ways, or simply that learning was fun. In addition, the students' commented on group work, collaboration and project work. Some of the answers even 
reflected collective resilience, an ability 'to adapt to changing demands, to recover, and to remain vigorous after the changes have occurred' (Schelvis et al. 2014, 631), as, for example, a quotation by a Finnish student indicates: 'The topic of our presentation was somewhat challenging but we managed even that.'

In all, 61 Finnish students answered the question about challenging or disruptive issues (92\% of the participants), and 56 items were categorised into the following groups, presented in Table 3.

Table 3. Categories of negative issues, number and percentage of items and examples or explanations of students' answers to open-ended questions Main category, $\mathrm{n}, \% \quad$ An example or an explanation Information search: 15 (27\%) 'It was difficult to find the necessary information' Difficult topic: $9(16 \%) \quad$ Concepts or the connection between the details of the information was difficult.

The project work process: 9 'We had to start almost from scratch. And it was $(16 \%)$ challenging. The background was not created for us'

Practical organising: $6(11 \%)$ This category is about how teachers had organised the practical work for students. This consisted of the time limits or having a large student group working at the same time (although the same student wrote that this was also positive), for example.

Uneven workload in the 'The workload was not shared equally among the group: $6(11 \%)$ participants'.

Project technology: $3(5 \%) \quad$ 'Working with Prezi at the same time with others' 
Other: $8(14 \%)$

Boring or uninteresting topic (3), the project disrupted

other courses (3), not understanding the project (2)

In addition, 14 students mentioned that there was nothing disruptive.

The answers to the open-ended question about challenges or disturbing issues were divided to many different issues. Information search and difficult topic were probably connected to each other: because the content was difficult, it was difficult to know which terms were correct and synthesise the knowledge. Project work was new to the students and for that reason, it was challenging to organise and to share the workload evenly.

\section{Bulgarian Students}

Bulgarian students' answers to the statements are presented in Figure 2.

I know how to use technology in multiple ways during collaborative work

I know how to develop productions collaboratively with others

I know how to work in a goal-oriented way in a group

I know how to take advantage of common discussions for deepening my understanding

I know how to discuss with others about the topics to be studied

I know how to analyse theoretically the topics to be studied

I know how to organise my studies purposefully

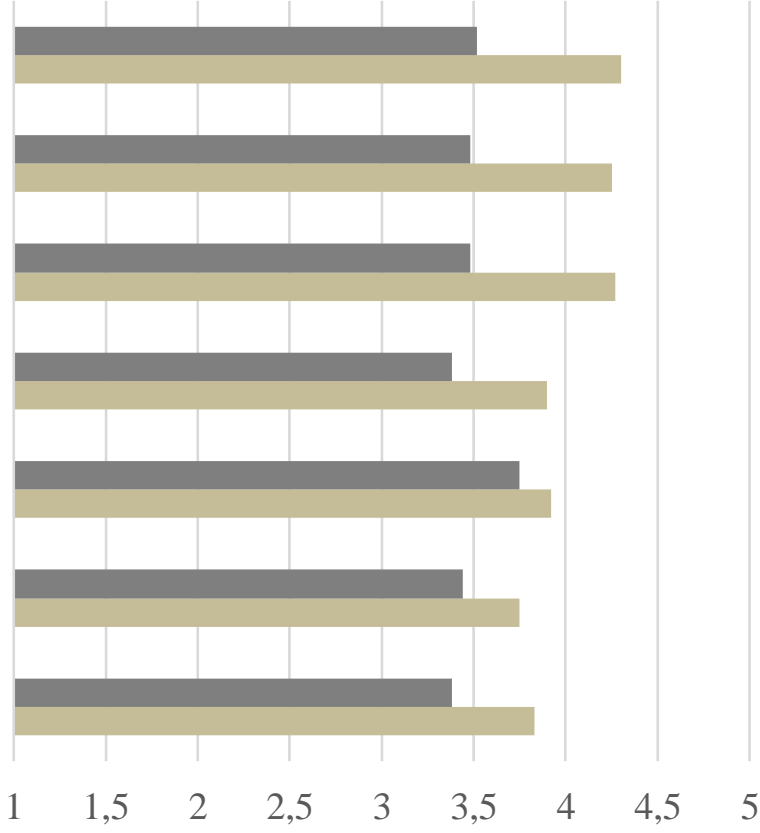

- Pre $(\mathrm{N}=52) \quad$ Post $(\mathrm{N}=52)$

Fig. 2. Bulgarian students' answers to pre- and post-statements

The Bulgarian students evaluated their skills as being 'good' in the pre-tests, and highest mean was in the statement about discussing the topics to be studied. The means of the post- 
tests were especially high in the statements about collaboration: using technology in collaborative work, developing productions with others and working goal-oriented in a group. The post-test results were higher in every statement, and there were statistically significant differences in each pre- and post-statements, p>.000 in all statements except in the statement 'I know how to discuss with others the topics to be studied', in which $\mathrm{p}=.002$. The means and standard deviations of the statements are presented in the Appendix 2.

Bulgarian students' answers to open-ended questions. Twenty-two students (42\% of the participants) answered the open-ended question about the positive issues during the course. Results of the 22 positive items mentioned are presented in Table 4.

Table 4. Categories of positive issues, number of items and examples of students' answers to open-ended questions

\begin{tabular}{|c|c|c|}
\hline Main category, N, \% & Subcategory, N & Example \\
\hline Learning: $13(59 \%)$ & $\begin{array}{l}\text { The content (5) } \\
\text { Something new (6) }\end{array}$ & 'Learning new design methods' \\
\hline & Learning for real life (2) & $\begin{array}{l}\text { 'The positive things from the } \\
\text { course is these which give us the } \\
\text { real view in the world and } \\
\text { technologies' }\end{array}$ \\
\hline Group work and & & 'It's positive that we can learn to \\
\hline collaboration $4(18 \%)$ & & $\begin{array}{l}\text { work collaboratively with more } \\
\text { people on a same task' }\end{array}$ \\
\hline Pedagogical & & 'The exercises. They are \\
\hline practices: $3(14 \%)$ & & diverse' \\
\hline
\end{tabular}

In addition, two (9\%) items 'everything'. 
The Bulgarian students appreciated learning the contents and learning for real life, similar to the Finnish students. The second issue was group work and collaboration, also similar among the Finnish students.

The second open-ended question was about the challenges or disruptions during the course and the results are presented in Table 5. In all, 22 Bulgarian students answered the question (42\% of the participants) and the results of the 20 items are presented in Table 5.

Table 5. Categories of positive issues, number of items and examples of students' answers to open-ended questions

\begin{tabular}{ll}
\hline Main category, n, $\%$ & Example \\
\hline Practical task related issues: $13(65 \%)$ & 'The deadlines and too little time' (6 \\
& students), 'Too much homework and little \\
& time to deal with it'. \\
Learning: $3(10 \%)$ & 'Independent learning' \\
Group work: $2(10 \%)$ & 'Group work' \\
Other: $2(15 \%)$ & 'Lacking practice', 'It has been challenging \\
& because it was hard'
\end{tabular}

In addition, two students mentioned that there was nothing disruptive.

Bulgarian students had fewer issues about challenges or disturbances. The main group consisted of practical task-related issues, like time limitations.

\section{Teachers' Evaluations of the Collaborative Planning and Realisation of the Courses}

The third research question was about teachers' experiences and evaluation of their course. In the following, we have presented categories of the items, the number of items, and examples. 
The Finnish teachers' evaluations. The evaluations of the Energy project in general were the following:

Successful issues in general: Six items, which consisted of things such as student motivation: 'I was surprised that they welcomed it so nicely', the larger entity in general, teachers' collaboration, the use of technology, and having the external expert.

Problems /challenges in general: 12 items. The problems mainly related to the pedagogical implementation, such as not using the contribution of the external expert well enough and missing the benefits of cross-fertilisation (4): 'I missed the view of other subjects, we could not see that we should have reserved place for the too large teaching group (2); and limited time (2).

Teachers also discussed pedagogical implementation, describing new practices and evaluating them:

Knowledge work practices: Eight items. Sharing was the issue mentioned most often (3), 'It was new for them to share [everything] from the beginning and they worked on the same document'. Other issues mentioned included the longitudinal process 'Perseverance work was totally new to some students'.

Group work: Seven items. Group work mainly succeeded well: 'Clearly you can get them work by throwing them in at the deep end; nobody becomes distressed, and clearly the one working alone becomes more distressed.' There was also a comment about the unequal workload within groups.

Changes compared with the previous iterations: Four items. The items mentioned were more time and in-depth work, external expert, and collaborative writing.

Teachers suggested several improvements, such as improving the last phase of the project, using the expertise of the external visitor or even visitors better, orienting students better, and using technology in a more effective way. 
The Bulgarian teacher's evaluation. The two Bulgarian teachers conducted the courses but only the principal (the theory teacher) answered the evaluation questions.

Successful issues in general were the division of students in teams of two, the creation of a common group for each class for interaction between students and the teacher, the creation of a virtual shared space for each team as well as the weekly assignments and the long-term project.

Problems / challenges were the allocation of responsibilities among team members and an effective way of reporting individual contributions.

The teacher's conclusion was that the new pedagogical practices, including the use of virtual environments, supported the development of teamwork and digital competencies well.

\section{Discussion}

We investigated how the trialogical design principles were applied to improve and create new pedagogical practices and courses at the upper secondary level in order to support students' learning of knowledge work competencies, and the students' and teachers' experiences of the new practices.

Although the design principles are challenging to implement in schools and classrooms, the present studies showed their strength as guiding tools for pedagogical planning. As noted by Lakkala et al. (2015), teachers usually emphasise some design principles more than others. In this case, teachers adopted the first, third and sixth design principles well, but the others were challenging. In the Bulgarian case, the solution of creating small collaborative tasks to support the main task (the first DP, shared object), was a combination of an open and authentic task and a school task. During the process, it turned out that even with good virtual guidance it was difficult for students to cope with the development of real-life projects. For this reason, the teachers divided the project into several sub-tasks with intermediate results and deadlines. The additional assignments were also 
collaborative but small ones. This reflects teachers' trust in traditional tasks in challenging situations, which was also noticed by higher education teachers (Lakkala et al. 2015). The second DP (Supporting integration of personal and collective agency and work) was also adopted mainly in a way that resembles traditional school practices. The fourth DP (Fostering long-term processes of knowledge advancement) the adoption was partial in the Finnish cases since teachers aimed to use the results for later projects, but this did not happen. The fifth DP (Promoting cross-fertilisation of various knowledge practices and artefacts) was taken into account in the Finnish case, but not in the Bulgarian case. At both schools, digital technology to support the work was used well, which indicates that upper secondary teachers are already familiar with digital technology. The realisation of the case was organised in the form of an inquiry process (in Finland) and a project work (in Bulgaria). These results are similar to the findings of Sansone, Bortolotti, and Buglass (2016), and indicate that it is important to model the pedagogical practices in more detail and not only at a theoretical level.

Students in both countries were very satisfied with the courses, and for both groups, this kind of collaborative and inquiry or project work learning was new. The challenges were positive ones: they supported motivation and engagement by requiring students to create their own solutions in their own work processes. The Bulgarian students' self-evaluations of their competencies after the course were more positive than those of the Finnish students', but the answers to the open-ended questions also revealed the Finnish students' promising experiences.

The participating teachers had created several additional activities of applying design principles in teaching which were necessary for the successful implementation. However, the results may suggest that projects of limited time, even though they are pedagogically sensible and well conducted, as in the Finnish case, do not have an effect on learning advanced general skills. The Bulgarian case was longer and thus more intensive and probably for these 
reasons, students' evaluations were that they had the competencies in question. It is important to give students opportunities to experience learning collaboration, learning how to manage difficult or challenging situations, and managing them together. It was striking how much effort students put into their work and how engaged they were, which resembles the findings of Sulptrine (2013) and Hufflinget al. (2014). This might indicate that the challenges of the assignments were at an appropriate level.

Teachers in both countries adopted the new pedagogical practices well and they implemented them in their local contexts in a creative way: the Finnish teachers also utilised the opportunity for pedagogical guidance during the project, for administrative requirements, and they created a new course. Teachers' collaboration was easy and effective, but the collaborative planning decreased towards the end of the process, which caused the project to become somewhat unintegrated. The Bulgarian teachers created a work-related project entity, simulating work-life practices. For them, it was challenging to allocate responsibilities between student team members and to report on the contributions. At the Finnish school, the course was conducted again in subsequent years and other teachers started to apply the same pedagogical approach (Ilomäki et al. 2017). At the Bulgarian school, the principal and another teacher applied the approach to a new course, and the approach was also applied by several other teachers (Stefanova and Gercheva 2015).

The study was a pilot study of only two cases, the participating teachers voluntarily decided to create new pedagogical practices, supported by a European project, and generalisation for 'ordinary' schools is not possible. For that, more research and practical experience is needed. One limitation was that the Bulgarian students answered in English, which first, probably reduced the number of students who answered the questions, and second, reduced the number of topics and the length of the answers. 


\section{Conclusions}

This study shows the opportunities and challenges of design principles, especially the second design principle of combining individual and collective assignments and the collaborative activities. This needs more examination and practical applications should be identified. Instead of using either individual or group tasks, teachers should combine meaningful challenges for both the individuals and for the group, and by emphasising students having more freedom to make their own choices, reflecting both the individual and team process, or by assessment practices. Similarly, the design principle of cross-fertilisation is not often used in upper secondary schools but in the Finnish case, it was used; these were new practices, but they succeeded. These are promising examples for other upper secondary schools. The success of implementing trialogical design principles in these cases was based on teachers' practical solutions which the design principled guided.However, there is a need to continue the investigation of classroom-level practices based on trialogical design principles in upper secondary school context.

In this study, the focus was on the pedagogical practices which were also investigated from the students' point of view. From their positive feedback, we may assume that students favour challenging activities. The nature and level of challenging activities should be among the aims of future research. However, the development of students' knowledge work competencies needs more practicing than only one or two courses, such as in-depth emphasis on the curriculum and on pedagogical practices.

The teachers in Finland and in Bulgaria were the first at their schools to apply the new pedagogical approach for creating a new course (in Finland) and for improving an existing course (in Bulgaria). Pedagogical improvements and applying new digital tools will always be demanding and these pioneering teachers could show examples of success to their colleagues. The participating teachers reported that they intended to apply the new practices 
in their courses in the future, and they would invite other colleagues from their schools to share in the development process. In this regard, the results of the experiments are sustainable.

The present study offers an example of revising existing pedagogical practices for developing educational practices in upper secondary schools, without major structural or curriculum changes. However, to disseminate these practices more widely among members of the school community, structural changes will often be needed for there to be pedagogical improvements. In this study, the Bulgarian school had considerable freedom to develop new practices, but for the Finnish school, the changes are more demanding - but not impossible.

\section{Acknowledgments}

The study was partially supported by the EU-funded KNORK project (543154-LLP-1-20131-FI-KA3-KA) and ARONI Research Project (285806) funded by the Academy of Finland. The authors are grateful to teachers and students who volunteered to participate in the study, to Dr Minna Lakkala for encouragement and ideas, and to the anonymous reviewers for their constructive comments.

\section{References}

Bell, S. 2010. 'Project-Based Learning for the 21st Century: Skills for the Future.' Journal of Educational Strategies, Issues and Ideas 83(2): 39-43. doi:10.1080/00098650903505415

Clarke, T., and E. Clarke, E. 2009. 'Born Digital? Pedagogy and Computer-Assisted Learning'. Education and Training 51(5-6): 395-407. doi: $10.1108 / 00400910910987200$ 
Cobb, P., J. Confrey, A. diSessa, R. Lehrer, and L. Schaube. 2003. 'Design Experiments in Educational Research'. Educational Researcher 32(1) 9-13. https://doi.org/10.3102/0013189X032001009

Collins, A., J.D., and K. Bielaczyc. 2004. 'Design Research: Theoretical and Methodological Issues'. Journal of the Learning Sciences 13(1): 15-42. doi: 10.1207/s15327809j1s1301_2

Davis, H. and L. Gueldenzoph Snyder. 2009. 'Work-Based learning: A Critical Link to Secondary Students Success'. Business Education Digest Issue XVIII: 1-11. European Commission. 2012a. EACAEA, Eurydice. 'Developing key competences at school in Europe: challenges and opportunities for policy'. Luxembourg: Publications Office of the European Union. https://www.ddooss.org/informes/School_in_Europe.pdf.

European Commission. 2012b. Communication from the Commission to the European Parliament, the Council, the European Economic and Social Committee and the Committee of the Regions. 'Rethinking education: Investing in skills for better socioeconomic outcomes'. http://eur-lex.europa.eu/legalcontent/EN/TXT/PDF/?uri=CELEX:52012DC0669\&from=FR

Francis, T., G. Østergaard, and S. Morse. 2013. 'Phenomenon-Based Learning in Agroecology: A Prerequisite for Transdisciplinarity and Responsible Action'. Agroecology and Sustainable Food Systems 37(1), 60-75. doi: $10.1080 / 10440046.2012 .717905$

Hammond, C., D. Karlin, and J. Thimonier. 2010. 'Creative research science experiences for high school students'. PLoS Biology 8(9): e1000447. https://doi.org/10.1371/journal.pbio.1000447

Hautamäki J., T. Säkkinen, M-L. Tenhunen, J. Ursin, J. Vuorinen, P. Kamppi, and G. KnubbManninen. 2012. Lukion tuottamat jatkokoulutusvalmiudet korkeakoulutuksen 
näkökulmasta. [The competencies produced by upper secondary school for further education from the higher education point of view]. Jyväskylä: Koulutuksen arviointineuvosto.

Heinström, J. and Sormunen, E. 2018. Structure to the unstructured - Guided Inquiry Design as a pedagogical practice for teaching inquiry and information literacy skills. A paper presented in ISIC 2018, The Information Behaviour Conference. Kraków, Poland, October 9-11.

Herring, J. E. 2011. 'From school to work and from work to school: information environments and transferring information literacy practices'. Information Research 16(2): paper 473. http://www.informationr.net/ir/16-2/paper473.html

Hilton, M. 2015. Preparing Students for Life and Work. In J. Pellegrino and M. Hilton (Eds). Education for Life and Work: Developing Transferable Knowledge and Skills in the 21st Century. The National Academies Press: Washington D.C. Available from: https://www.researchgate.net/publication/265242593_Education_for_Life_and_Work _Developing_Transferable_Knowledge_and_Skills_in_the_21st_Century. Retrieved Sep 102018.

Huffling, L., T. Tomasek, C. Matthews, A. Benavides, H. Carlone, and T. Hegedus. 2014. 'Using Mobile Devices in FIELD SCIENCE.' The Science Teacher 81 (6): 35-40. https://search-proquest com.libproxy.helsinki.fi/docview/1559837092?accountid=11365.

Ilomäki, L., M. Lakkala, A. Toom, \& H. Muukkonen. 2017. 'Teacher learning within a multinational project in an upper secondary school'. Education Research International. Article ID 1614262: 1-13. doi: 10.1155/2017/1614262

Ilomäki, Lakkala, Muukkonen and Toom. Knowledge assignments in upper secondary schools. Work in progress. 
Ilomäki, L., S. Paavola, M. Lakkala, and A. Kantosalo. 2014. 'Digital competence - an emergent boundary concept for policy and educational research'. Education and Information Technologies 21(3): 655-679. doi:10.1007/s10639-014-9346-4.

Kay, K. 2009. Middle Schools Preparing Young People for 21st Century Life and Work. Middle School Journal; 40(5). Retrieved in ERIC.

Kiili, C. 2012. Online reading as an individual and social practice. Jyväskylä Studies in education, psychology and social research 441. University of Jyväskylä. http://urn.fi/URN:ISBN:978-951-39-4795-8

Klusek, L. and J. Bernstein. 2006. 'Information literacy skills for business careers: Matching skills to the workplace'. Journal of Business and Finance Librarianship 11(4), 3-21. doi: 10.1300/J109v11n04-02.

Krokfors, L. 2017. 'Opetussuunnitelman pedagogiset mahdollisuudet - opettajat uuden edessä'. [The pedagogical possibilities of curriculum] In Opetussuunnitelmatutkimus. Keskustelun avauksia suomalaiseen kouluun ja opettajankoulutukseen. T. Autio, L. Hakala, and T. Kujala. 247-266. Tampere University Press. http://urn.fi/URN:ISBN:978-952-03-0635-9

Lakkala, M., L. Ilomäki, and A. Kantosalo. 2011. 'Which pedagogical practices and methods best support learning digital competences? In depth.' LINKED portal. European Schoolnet. Brussels. http://linked.eun.org/web/gues t/in-depth5

Lakkala, M., L. Ilomäki, S. Paavola, K. Kosonen, and H. Muukkonen. 2012. 'Using Trialogical Design Principles to assess pedagogical practices in two higher education courses'. In Collaborative Knowledge Creation: Practices, Tools, Concepts, edited by A. Moen, A. Mørch and S. Paavola, p. 141-161. Rotterdam: Sense Publishers. 
Lakkala, M., A. Toom, L. Ilomäki, and H. Muukkonen. 2015. 'Re-designing university courses to support collaborative knowledge creation practices'. Australasian Journal of Educational Technology 31(5). 521-536. doi: https://doi.org/10.14742/ajet.2526.

Lundahl, L., I. Erixon Arreman, U. Lundström, and L. Rönnberg. 2010.' Setting Things Right? Swedish Upper Secondary School Reform in a 40-Year Perspective'. European Journal of Education. Special Issue: Knowledge, Globalisation and Curriculum 45(1): 46-59. http://dx.doi.org/10.1111/j.1465-3435.2009.01414.x

Muukkonen, H., M. Lakkala, A. Toom, and L. Ilomäki. 2017. 'Assessment of competences in knowledge work and object-bound collaboration during higher education courses'. In Higher Education Transitions: Theory and Research, edited by E. Kyndt, V. Donche, K. Trigwell, and S. Lindblom-Ylänne. EARLI book series New Perspectives on Learning and Instruction, 288 - 305. London, UK: Routledge.

Newman, I., C.S. Ridenouer, C. Newman, and G. M. P. DeMarco Jr. 2003. ‘A typology of research purposes and its relationship to mixed methods'. In Handbook of Mixed Methods in Social and Behavioral Research, edited by A. Tashakkori and C. Teddle, 167-188. Sage Publications: Thousand Oaks.

Nikolov, D. 2015. 'The Robot Track Gathered School, University and Business' (in Bulgarian). Technical Vanguard 2. Retrieved August 10, 2015 http://81.161.244.115/nta.tusofia.bg/nta517_2015_02.pdf

Opetushallitus. 2015. Lukion opetussuunnitelman perusteet 2015. [The basis of the curriculum 2015 for upper secondary school]. Määräykset ja ohjeet 2015:48. Next Print: Helsinki.

OECD 2010. The Organisation for Economic Co-operation and Development. Are the New Millenium Learners Making the Grade? Technology use and educational performance in PISA. OECD Publishing: Paris, France. 
OECD 2015, Students, Computers and Learning: Making the Connection, PISA, OECD Publishing, Paris, https://doi.org/10.1787/9789264239555-en.

Paavola, S. and Hakkarainen. K. 2009. 'From meaning making to joint construction of knowledge practices and artefacts - A trialogical approach to CSCL'. In Computer supported collaborative learning Practices: CSCL2009 conference Proceedings, edited by C. OMalley, D. Suthers, P. Reimann, and A. Dimitracopoulou, 83-92). International Society of the Learning Sciences (ISLS): Rhodes, Creece.

Paavola, S., M. Lakkala, H. Muukkonen, K. Kosonen, and K. Karlgren, K. 2011. 'The roles and uses of design principles for developing the trialogical approach on learning'. Research in Learning Technology 19(3): 233-246. doi: https://10.1080/21567069.2011.624171

Pitura, J. and Berlinska-Kopec, M. 2018. 'Learning English While Exploring the National Cultural Heritage: Technology-Assisted Project-Based Language Learning in an Upper-Secondary School'. Teaching English with Technology, 18 (1), 37-52. Retrieved from http://cejsh.icm.edu.pl/cejsh/element/bwmeta1.element.desklight97fa9a1c-f387-42eb-9b59-5c38068ccd0a

Rasmussen, I. and Å. Hagen. 2015. 'Facilitating students individual and collective knowledge construction through microblogs'. International Journal of Educational Research 72:149-161. http://dx.doi.org/10.1016/j.ijer.2015.04.014

Ruskovaara, R. and T. Pihkala. 2015. 'Entrepreneurship Education in Schools: Empirical Evidence on the Teachers Role'. The Journal of Educational Research 108(3): 236249. doi: https://10.1080/00220671.2013.878301

Sansone, N., I. Bortolotti, and S. Buglass, S. 2016. 'The Trialogical Learning Approach in Practices: Reflections from pedagogical cases'. Qwerty - Open and Interdisciplinary 
Journal of Technology, Culture and Education 11(2): 99-120.

http://www.ckbg.org/qwerty/index.php/qwerty/article/view/240

Sansone, N., D. Cesareni, I. Bortolotti. 2018 (in press). 'Promoting XXI century skills in Higher Education through collaboration and activity. In Employability and Competences. Innovative Curricula for New Professions, edited by V. Boffo, and M. Fedeli. Firenze University Press: Firenze.

Schelvis, R. M., G. I. Zwetsloot, E. H. Bos, and N. M. Wiezer. 2014. 'Exploring teacher and school resilience as a new perspective to solve persistent problems in the educational sector'. Teachers and Teaching 20(5), 622-637. https://doi.org/10.1080/13540602.2014.937962

Shuptrine, C. 2013. 'Improving College and Career Readiness through Challenge-Based Learning.' Contemporary Issues in Education Research 6(2): 181-188. https://eric.ed.gov/?id=EJ1073224

Stefanova S. and T. Vasileva. 2014.' Trialogical Approach to Knowledge Practices in CAD Education'. Annual Journal of Electronics 8:150-153. http://ecad.tusofia.bg/et/2014/ET2014/AJE_2014/150-S_Stefanova.pdf

Stefanova, S., and R. Gercheva. 2015. 'Application of Trialogical Design Principles to Practical Education in Networking Technologies'. Annual Journal of Electronics: 6165. http://ecad.tu-sofia.bg/et/2015/ET2015/AJE-2015/061Paper-S_Stefanova.pdf

Tremblay, K., D. Lalancette, and D. Roseveare. 2012. Assessment of Higher Education Learning Outcomes Feasibility Study Report Volume 1 - Design and Implementation. OECD 2012. www.oecd.org/education/skills-beyondschool/AHELOFSReportVolume1.pdf

Tynjälä, P. 2008. 'Perspectives into learning at the workplace. Review'. Educational Research Review 3:130-154. https://doi.org/10.1016/j.edurev.2007.12.001 
Wang, C.K.J., W.C. Liu, C. Koh,, O.S. Tan, \& J. Ee,. 2011. 'A Motivational Analysis of Project Work in Singapore Using Self-Determination Theory'. The International Journal of Research and Review7(1): 45-65.

Vasileva T. and S. Stefanova. 2014. 'Integration between Technical University and Technological School'. XII International Conference on Systems, Automatic Control and Measurements - SAUM 2014: 269-272, Nis, Serbia.

Vasileva T., and V. Tchoumatchenko. 2014. 'Promoting Knowledge Practices in Electronic Education', Annual Journal of Electronics (8): 158-161.

Vasileva T., V. Tchoumatchenko and M. Manoeva. 2015. 'Cloud Computing in Collaborative Learning in Electronics'. Annual Journal of Electronics (9): 57-60.

Voogt, J., Pareja Roblin, N. 2012. A Comparative Analysis of International Frameworks for 21st Century Competences: Implications for National Curriculum Policies, Journal of Curriculum Studies. 44(3), 299-321. https://doi.org/10.1080/00220272.2012.668938 


\section{Appendix 1.}

Means and Standard Deviations of Finnish Students'Pre and Post Questionnaires

\section{Finnish students}

Pre $(\mathrm{N}=66) \quad$ Post $(\mathrm{N}=67)$

Mean Standard Mean Standard

Variables

deviation

deviation

I know how to organise my studies

$\begin{array}{llll}3.6 & 0.86 & 3.5 & 0.83\end{array}$

purposefully

I know how to analyse theoretically the topics

$\begin{array}{llll}3.6 & 0.63 & 3.5 & 0.73\end{array}$

to be studied

I know how to discuss the topics to be studied

$\begin{array}{llll}4.0 & 0.71 & 4.0 & 0.70\end{array}$

with others

I know how to take advantage of common

$\begin{array}{llll}3.9 & 0.71 & 3.9 & 0.70\end{array}$

discussions for deepening my understanding

I know how to work in a goal-oriented way in

$\begin{array}{llll}4.0 & 0.60 \quad 4.0 & 0.65\end{array}$

a group

I know how to develop productions

collaboratively with others

$\begin{array}{llll}3.8 & 0.82 & 3.9 & 0.74\end{array}$

I know how to use technology in multiple

$\begin{array}{llll}3.8 & 0.97 & 3.9 & 0.76\end{array}$

ways during collaborative work 


\section{Appendix 2}

Means and Standard Deviations of Bulgarian Students'Pre and Post Questionnaires

\section{Bulgarian students}

Pre $(\mathrm{N}=52)$

Post $(\mathrm{N}=52)$

\section{Standard}

Standard

Variables

Mean deviation

Mean

deviation

I know how to organise my

studies purposefully

$\begin{array}{llll}3.4 & 1.14 & 3.8 & 1.04\end{array}$

I know how to analyse

theoretically the topics to be

3.4

1.00

3.8

0.93

studied

I know how to discuss the

topics to be studied with others

3.8

0.97

3.9

0.86

I know how to take advantage

of common discussions for

3.4

1.01

3.9

0.85

deepening my understanding

I know how to work in a goal-

oriented way in a group 
I know how to develop

productions collaboratively

3.5

0.94

4.3

0.71

with others

I know how to use technology

in multiple ways during

3.5

1.08

4.3

0.73

collaborative work 